\title{
Efforts in Increasing the Customer Loyalty
}

\author{
Tontowi \\ University of Sunan Giri, Faculty of Social and Politic Science, Jl. Brigdjen Katamso II Waru Surabaya, \\ Surabaya
}

\begin{abstract}
This study aims to examine the effect of marketing public relations, service quality, and brand awareness on customer loyalty of PT Pos Indonesia. The population is the consumers of PT Pos Indonesia. The 100 samples are selected using the convenience random sampling method. Data were collected by questionnaires distributed directly to consumers. The obtained data are analyzed by multiple regression analysis. The results are follows. First, marketing public relations has a positive and significant effect on customer loyalty. Second, Service quality has a positive and significant effect on customer loyalty. Third, brand awareness has a positive and significant effect on customer loyalty. Marketing public relations, service quality and brand awareness simultaneously also have positif and significant effect on customer loyalty.
\end{abstract}

Keywords: Marketing Public Relations, Service Quality, Brand Awareness, Customer Loyalty

DOI: $10.7176 / \mathrm{JMCR} / 84-02$

Publication date: January $31^{\text {st }} 2022$

\section{INTRODUCTION}

Competition in logistics business is tight and increasingly wide open for both new and old players in Indonesia. Every company must have a target that must be achieved. The applied strategy must also be appropriate in order it can develop as expected. Companies must take advantage of every opportunity and threats to determine the right strategy to run. A customer continuously and repeatedly comes to same place to satisfy his desire by having a product or service and paying them.

The modern era shows rapid development of technology and has been widely used in various circles of society. One part of the technology is the internet. The e-Marketer market research institute showed the population of Internet users in Indonesia reached 102.8 million people in 2016 and is among the $6^{\text {th }}$ largest internet user countries in world. The e-Marketer estimates that Indonesian netters will reach 112.6 million people in 2017 , beating Japan in $5^{\text {th }}$ place, where the growth in number of internet users is slower. The internet advent gives opportunity to the business people to start business online where the role of delivery service companies is very important.

Kotler and Keller (2015: 36) defined service as an action or performance offered to another that is essentially intangible and does not result in any ownership. Its production may or may not be linked to a physical product. Nonetheless, a growing number of manufacturers, distributors, and retailers are providing value-added services, or excellent customer service, to differentiate them.

In this case the service quality is a determining factor of customer loyalty after making a purchase and product usage. The good service quality can fulfill the desires and needs of consumers for a product, thus triggering consumers to use these services continuously. This is called customer loyalty. Oliver in Hidayat (2015: 36) stated that loyalty is defined as a deeply held commitment to buy or re-support a preferred product or service in future even though the influence of the situation and marketing efforts has the potential to cause customers to switch.

Kotler \& Keller (2015:61) stated that in addition to service quality, services must also consider brands for positioning and targeting different market segments. The services are intangible and customers often make decisions and arrangements about services in places far from actual location of the service (at home or in office), and the brand reminders are very important. A memorable brand name becomes a very important element. Other brand elements such as logos, character symbols and slogans can also accompany the brand name to build brand awareness and brand image.

The brand awareness is the ability of a brand to appear in minds of consumers when they are thinking about a particular product and how easily the name is raised. Brand awareness is a basic dimension in brand equity. A brand has no equity until consumers are aware of the brand's existence. The new brand must be able to achieve brand awareness. Then, all brands must strive to maintain brand awareness (Suyatno, 2013: 70).

Hasan (2013:32) explained that company's performance assessment can be seen from growth dimension and related finance, which can be related to company's past performance. The second dimension is observing aspects of the company's current performance. This relates to non-financial aspects, which are still vital for company, such as aspects of customer performance. Customer performance means that entrepreneur should have a satisfied and loyal customer base, it is important for company to remain competitive. The third dimension is futureoriented company performance, for example aspects of company innovation. The innovation will lead to 
competitive advantage where the indicators of innovation involve questions related to company's ability to develop new products, processes or services.

Zainal and Muhibudin (2015:12) revealed that maintaining loyal customers and keeping them from switching to similar goods delivery services are important things to bind customers. One effective way to achieve customer loyalty is through marketing public relations activities. Public relations marketing or marketing in public relations and publicity is a variation programs designed to promote or protect the image of a company or its individual products. Based on above description, this research examines the effect of marketing public relations, service quality and brand awareness on customer loyalty.

\section{LITERATURE REVIEW}

\section{Marketing}

The American Marketing Association (AMA) defines marketing as the process of planning and executing the conception, pricing, promotion, and distribution of ideas, goods and services to create exchanges that will satisfy the goals of individuals and organizations. Kotler and Amstrong (2015) defined the marketing as the activity of analyzing, organizing, planning, and supervising the resources, policies, and activities to affect the company's customers with aim to satisfy the needs and desires of selected customer groups for profit.

Based on above definition, it can be concluded that marketing is the activity of a company aimed at meeting the needs and wants of consumers by creating goods and services. It can be done by setting prices, and distributing them to market according to needs and purchasing power of consumers or customers.

\section{Service}

Adam (2015: 10) defined service as something from one party to another which basically intangible and does not create a transfer of ownership. Santon in Alma (2013: 243) stated that a service is something that can be identified separately, intangible, offered to meet needs. Services can be produced by tangible or intangible objects.

Lovelock (2011) defined service as an economic activity offered by one party to another. The activities are done within a certain period of time (time-based), in form of an activity (performances) that will bring the desired results to recipient, object, or other assets that are the responsibility of the buyer. The customers expect to get value from access to certain goods, labour, expertise, facilities, networks and systems in exchange for money, time and effort, service, but customers usually will not get the property rights of these elements.

\section{Marketing Public Relations}

Kotler and Amstrong (2015) stated that public relations (PR) is a management function to evaluate public attitudes, identifies the policies and procedures of an individual or organization based on public interest and runs programs to get public understanding and acceptance. Lovelock and Jonchen (2011) defined the public relations as an art and social science that can be used to analyze trends, predict their consequences, advise organizational leaders, and implement planned programs of activities that serve the public interest.

Lupiyoadi (2013) also explained that public relations was something that summarizes the overall planned communication, both internally and externally, between an organization and all its audiences in order to achieve specific goals based on mutual understanding. Based on above three expert definitions, it can be concluded that public relations is the art to create a better public understanding to deepen the public trust in an individual or organization.

\section{Service quality}

Hardiansyah (2011: 36) stated that service quality was a dynamic condition related to products, services, people, processes and environment to meet or exceed the expectations. Kotler and Amstrong (2015) stated that service quality was everything that can meet the desires or needs of customers.

Lovelock and Jonchen (2011) defined service quality as the service provided to customers in accordance with service standards that have been standardized as guidelines in providing services. The service quality is the overall characteristics of a product or service to affect its ability to satisfy stated or implied needs.

\section{Brand Awareness}

Suyatno (2013: 70) stated that brand awareness was the ability of a brand to appear in minds of consumers when they are thinking about a particular product and how easily the name is raised. Brand awareness is a basic dimension in brand equity. A brand has no equity until consumers are aware of the brand's existence. The new brand must be able to achieve brand awareness. Then, all brands must strive to maintain brand awareness.

Durianto, Sugiarto and Sitinjak (2014: 54) explained that brand awareness was the ability of a potential buyer to recognize and recall a brand as part of a certain product category. The part of a category needs to be emphasized because there is a strong relationship between the product category and the brands. Brand awareness 
requires continuum ranging from an uncertain feeling that a particular brand has been known before, so that consumers believe that product is the only brand in a product group. This continuum can be represented in different levels of brand awareness.

\section{Customer loyalty}

Hasan (2013:134) explained that loyalty is a psychological condition (attitude and behavioral) related to attitudes towards products, consumers will create beliefs, determine likes or dislikes, and decide whether they will buy the product. Attitude dimension is the customer's intention and preference to buy a particular service or product. Intention to buy or recommend and preference for a company is an important factor in determining business in future. Kotler and Amstrong (2015) stated that customer loyalty is a combination of intellectual and emotional processes between customers and company. Loyalty is elusive (cannot be measured) and intangible (cannot be managed).

Attitude measures loyalty as an interval or continuum scale (a degree of loyalty). Therefore, main purpose of measuring loyalty based on an attitude perspective is not to find out whether a person is loyal or not, but to understand intensity of his loyalty to a particular brand or store (Ali Hasan: 139).

\section{Conceptual Framework and Hypothesis}

The market public relation, service quality and brand awareness affect on customer loyalty. Based on above description, the conceptual framework of this research can be shown in figure 1.

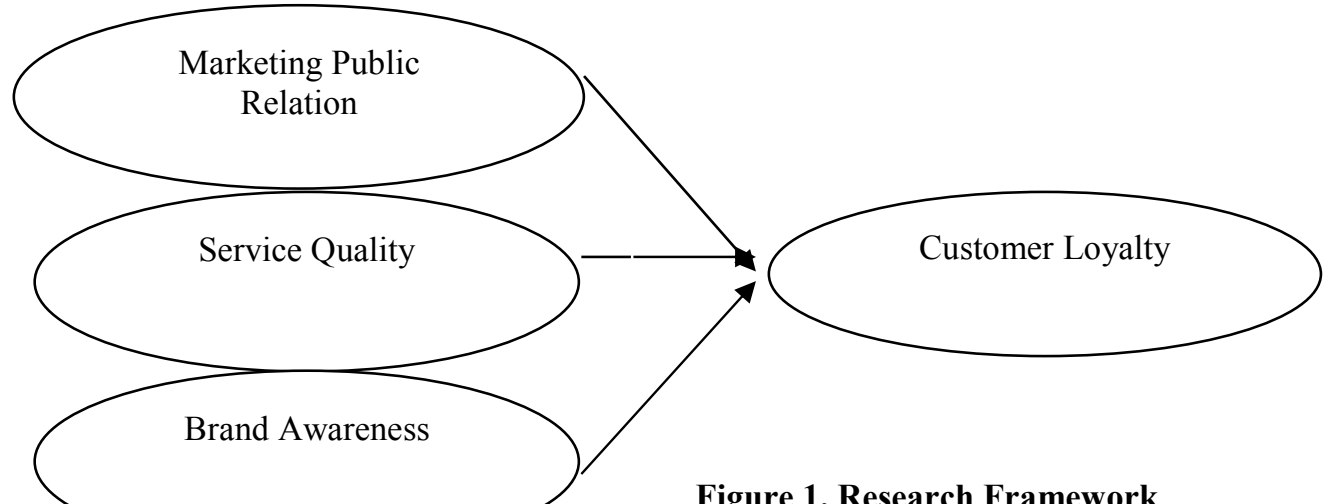

Figure 1. Research Framework

Based on research framework, the research hypothesis can be formulated below.

H1. The marketing public relations variable has a positive and significant effect on customer loyalty at PT Indonesia Post in Surabaya.

H2. The service quality variable has a positive and significant effect on customer loyalty at PT Indonesia Post in Surabaya.

H3. Brand awareness variable has a positive and significant effect on customer loyalty at PT Indonesia Post in Surabaya.

\section{RESEARCH METHODS}

This research was done using quantitative methods (Sujarweni, 2015: 89). This study uses four variables, consisting of one dependent variable of customer loyalty and three independent variables of marketing public relations, service quality and brand awareness (Sugiyono, 2016: 3). The quantitative data is in form of numbers whose nature can be calculated and measured in number to be processed using statistical methods. The data sources of primary data obtained directly collected from respondents and secondary data obtained from journals, books, previous research (Masyhuri, 2011:153).

The study populations are all consumers who buy services at PT Pos Indonesia in Surabaya. The sample of this study was 100 consumers selected by convenience random sampling method. Data were collected using a 5point Likert scale questionnaire, starting from $5=$ strongly agree, $4=$ agree, $3=$ neutral, $2=$ disagree and $1=$ strongly disagree (Sugiyono, 2016:137). The data obtained were then analyzed for validity and reliability, followed by multiple regression analysis and was done using the statistical program SPSS 22 (Statistic Program for Social Science)

\section{RESULTS AND DISCUSSION}

The majority of respondents (55\%) are male while the remaining 45\%) are female. The majority of respondents are aged 21-30 years (60\%) while the rest are above 31 years old. The majority of respondents $(38 \%)$ have a 
bachelor's degree, while the rest have primary to high school education. The majority of respondent income are 1-3 million (61\%), while those under 1 million are only $4 \%$ and rest are above 3 million.

To support the regression analysis, it is necessary to test the validity and reliability of the questionnaire, followed by classical assumption test. After all the requirements of validity, reliability and classical assumptions are met, and then the test is done using multiple regression analysis using SPSS Version 22. The results of the analysis show $\mathrm{r}$ arithmetic $>\mathrm{r}$ table or sig value $<0.05$. This means that all of the question items are valid. Reliability test is done by looking at alpha value. The test results show that all alpha values are greater than 0.6 , this means that answers given by respondents are reliable.

Classical assumption test includes normality, multicollinearity, autocorrelation and heteroscedasticity tests. The results of the normality test show that confounding variable or residual has a normal distribution because it has a significance value greater than 0.05 . It means that data has normal distribution. The multicollinearity test examines a correlation between the independent variables in regression model. The analysis results show that all variables are independent from multicollinearity (non-multicollinearity). This is evidenced by all variables having tolerance values $>0.1$ and VIF $<10$. The autocorrelation test examines a correlation between the error or disturbance of $t$ period and confounding error of previous period $(t-1)$ in linear regression model. The results of autocorrelation test show that Durbin Watson value of 1.827 is between dU to 4-dU. There is no autocorrelation in research models. Heteroscedasticity test examines the inequality of variance from residual of one observation to another observation. The results of heteroscedasticity test show that all variables have a significance value $>$ 0.05. This means that all variables are free from heteroscedasticity (Sugiyono, 2016:137). The next step is multiple regression analysis. The results of the analysis are shown in table 1.

Table 1. Multiple Linear Regression Test Results

Dependent Variable: Human development index

\begin{tabular}{|c|c|c|c|c|}
\hline \multicolumn{2}{|c|}{ Variable } & Unstandardized coefficient B & $t$ count & Sig. \\
\hline \multicolumn{2}{|c|}{ Marketing public relation } & , & 2.211 & .020 \\
\hline \multicolumn{2}{|c|}{ Service quality } & .449 & 3.263 & .000 \\
\hline \multicolumn{2}{|c|}{ Brand awareness } & .317 & 2.324 & .022 \\
\hline Constant & \multicolumn{4}{|c|}{0.962} \\
\hline $\mathrm{F}_{\text {count }} ;$ Sig & \multicolumn{4}{|c|}{53,$348 ; 0.000$} \\
\hline $\mathrm{R}_{\text {square }}$ & \multicolumn{4}{|c|}{0.772} \\
\hline
\end{tabular}

Source: Data processed by SPSS 22

Table 1 show that value of determination coefficient ( $\mathrm{R}$ square) for multiple regressions between the independent variables and dependent variable is 0.772 . This shows that marketing public relation, service quality and brand awareness simultaneously affect on customer loyalty by $77.2 \%$ and remaining $22.8 \%$ are affected by other factors that are not investigated in this research.

Constants are fixed numbers without the effect on other variables. Table 1 shows the constant value is 0.962 . This means that value of consumer loyalty will be 0.962 without being affected by marketing public relation, service quality and brand awareness variables. The significance of $F$ test (probability) is $0.000(p<0.05)$ and calculated $\mathrm{F}$ value is 53.348 greater than the $\mathrm{F}$ table (2.81). It means that marketing public relations, service quality, and brand awareness simultaneously affect on consumer loyalty.

Marketing public relations regression coefficient is 0.317 , indicating a positive (unidirectional) relationship between marketing public relations and customer loyalty at PT Pos Indonesia in Surabaya. Therefore, first hypothesis that marketing public relations has a positive and significant effect on customer loyalty is accepted. These results indicate that better marketing public relations will increase the customer loyalty to company. In other words, if the marketing public relations variable increases by 1 unit, then customer loyalty will increase by 0.317 assuming the other variables are constant. The results of this study are in line with research of Zephaniah et al. (2020) that good public relations will be able to increase consumer loyalty.

The service quality regression coefficient of 0.349 indicates the direction of the positive relationship (unidirectional) between the service quality variable and customer loyalty of PT Pos Indonesia in Surabaya. Therefore, second hypothesis that service quality has a positive and significant effect on customer loyalty is accepted. These results indicate that better the service quality provided by PT Pos Indonesia employees in Surabaya, more customer loyalty to company will increase. In other words, if the service quality variable increases by 1 unit, then customer loyalty will increase by 0.349 assuming the other variables are constant. The results of this study are consistent with research of Steinhoff and Zondag (2021) who found that service quality had a positive and significant effect on consumer loyalty.

Regression coefficient of brand awareness is 0.362 , indicating a positive (unidirectional) relationship between brand awareness and customer loyalty at PT Pos Indonesia in Surabaya. Therefore, third hypothesis that brand awareness has a positive and significant effect on customer loyalty is accepted. In other words, if the brand awareness variable increases by 1 unit, then customer loyalty will increase by 0.362 assuming the other variables 
are constant. The results of this study are consistent with research of Abou-Shouk and Soliman $(2021,2021)$ which found that brand awareness has a significant effect on consumer loyalty.

\section{CONCLUSIONS AND SUGGESTIONS}

The research examines the effect of marketing public relation, service quality and brand awareness on customer loyalty. The conclusions of this study can be presented below.

1. Marketing public relations has a positive and significant effect on customer loyalty.

2. Service quality has a positive and significant effect on customer loyalty.

3. Brand awareness has a positive and significant effect on customer loyalty.

Based on above conclusions, the PT Pos Indonesia company should improve the customer loyalty by making improvements in promotions to attract consumers, including monitoring new product launch events, building consumer interest in a product category, defending products that have problems and build a corporate image to support the service program. In addition, improvements need to be made in responding to the customer complaints. Last, promotions should be done repeatedly to attract new customers and improve the service quality such as the accuracy and speed of goods, as well as loss of goods guarantees to keep customers loyal.

This research has some limitation. First limitation is the limited variables and population. Future research should add other research variables and expand population and years of research to make complete research. Other research variables that can be used are discount rate. Second limitation is the study uses multiple regression analysis, future researchers should use a more thorough analysis, such as PLS or AMOS.

\section{REFERENCE}

Abou-Shouk, Mohamed and Mohammad Soliman, 2021. The impact of gamification adoption intention on brand awareness and loyalty in tourism: The mediating effect of customer engagement. Journal of Destination Marketing \& Management, Volume 20.

Adam, Muhammad. 2015. Manajemen Pemasaran Jasa Teori dan Aplikasi. Cetakan kesatu : Bandung. Alfabeta, CV.

Alma, Buchari. 2013. Manajemen Pemasaran Dan Pemasaran Jasa. Cetakan kesepuluh. Bandung: Alfabeta, CV.

Arikunto, Suharsimi. 2013. Prosedur Penelitian Suatu Pendekatan Praktik. Cetakan ke 15. Jakarta : Rineka Cipta, PT

Durianto, D, Sugiarto \& Sitinjak.2014. Brand Equity Ten Strategy Memimpin Pasar. Jakarta : Gramedia Pustaka Utama, PT

Ghozali, Imam. 2013. Aplikasi Analisis Multivariate dengan Program SPSS. Edisi Ketujuh. Semarang : Badan Penerbit Universitas Diponegoro.

Hardiansyah. 2011. Kualitas Pelayanan Publik. Yogyakarta. Gava Media.

Hasan, Ali. 2013. Marketing dan Kasus-Kasus Pilihan. Yogyakarta : CAPS (Center For Academic Publishing Service).

Kotler, Philip and Amstrong. 2015. Marketing Management. $16^{\text {th }}$ Edition. Pearson Prentice Hill

Kotler, Philip dan Gary Amstrong. 2012. Principles Of Marketin, Global Edition, 14 Edition, Pearson Education

Lena Steinhoff and Marcellis M. Zondag. 2021. Loyalty programs as travel companions: Complementary service features across customer journey stages. Journal of Business Research.

Lovelock, Christopher and Wirtz, Jonchen. 2011. Service Marketing : People, Technology, Strategy. $7^{\text {th }}$ Edition. New Jersey : Pearson Education Inc.

Lupiyoadi, Rambat. 2013. Manajemen Pemasaran Jasa. Cetakan ketiga. Jakarta : Salemba Empat.

Masyhuri. 2011. Metodologi Riset Manajemen Pemasaran. Cetakan kedua. Malang : UIN Malik Press

Mukarom, Z dan Muhibudin, L. 2015. Manajemen Public Relation. Bandung : Pustaka Setia, CV.

Runguti, F. 2016. Measuring Customer Satisfaction - Teknik Mengukur dan Strategi Meningkatkan Kepuasan Pelanggan. Jakarta : Gramedia Pustaka Umum, PT

Setiyaningrum, Ari.2015. Prinsip-Prisip Pemasaran. Yogyakarta : ANDI

Shinta, Agustina. 2011. Manajemen Pemasaran. Cetakan pertama. Malang : UB Press

Sugiyono. 2013.Metode Penelitian Kuantitatif, Kualitatif, dan Kombinasi (Mixed Methods). Bandung : Alfabeta.

Sugiyono. 2016. Metode Penelitian Kuantitatif dan Kualitatif $R \&$ D. Bandung : Alfabeta

Sujarweni, Wiratna. 2015. Metodologi Penelitian Bisnis \& Ekonomi. Yogyakarta : PUSTAKA BARU PRESS

Sunyoto, Danang. 2013. Teori Kuesioner dan Analisis Data untuk Pemasaran dan Perilaku Konsumen. Yogyakarta : Graha Ilmu.

Suyatno. 2013. Membangun Citra Merek. Yogyakarta : AMIKOM

T, Hidayat. 2015. Pengaruh Marketing Public Relation Terhadap Loyalitas Pelanggan. Jakarta : Gramedia Pustaka Umum, PT

Yuniarti, Vinna Sri. 2015. Perilaku Konsumen. Cetakan 1. Bandung : Pustaka Setia, CV. 
Zephaniah, Chinedu Ogbonnaya, Ike-Elechi Ogba and Ernest Emeka Izogo. 2020. Examining the effect of customers' perception of bank marketing communication on customer loyalty. Scientific African, Volume 28. 